\title{
Siberian Development Vector: Based on Cooperation and Interaction
}

\author{
V. A. Kryukov ${ }^{a, *}$, B. L. Lavrovskii ${ }^{a}$, V. E. Seliverstov ${ }^{a}$, V. I. Suslov ${ }^{a}$, and N. I. Suslov ${ }^{a}$ \\ ${ }^{a}$ Institute of Economics and Industrial Engineering, Siberian Branch, Russian Academy of Sciences, Novosibirsk, 630090 Russia \\ *e-mail: kryukov@ieie.nsc.ru \\ Received April 16, 2020; revised April 20, 2020; accepted May 5, 2020
}

\begin{abstract}
The article reflects the position held by the Institute of Economics and Industrial Engineering, Siberian Branch of the Russian Academy of Sciences regarding the problems and prospects of the socio-economic, scientific, and technological development of Siberia and the directions of strengthening its positions in the world and Russian space. The main development problems of Siberia and the Siberian Federal District are identified, taking into account modern challenges and threats. It is shown that the recovery of the Siberian economy as a whole and the regions of the Siberian Federal District, in particular, should be based on a significant increase in investment activity at all levels: macroregional, regional, and municipal. Proposals are made on a package of new Siberian investment projects with a focus on "embedding" Siberia in high-tech niches of the Russian and world economies, as well as on a system of priority measures that should be taken at the national, interregional, and regional levels.
\end{abstract}

Keywords: Siberia, Siberian Federal District, program- and project-oriented approach, interregional interactions, connectivity of economic space, innovative development, cross-border interactions

DOI: $10.1134 / \mathrm{S} 1075700720050111$

Introduction (problem situation). In a report at the St. Petersburg International Economic Forum on June 7, 2019, President of the Russian Federation V.V. Putin emphasized: "Today we need to think about raising the vast territories of Central and Eastern Siberia, carefully prepare and calculate, and coordinate a development plan. This macroregion is rich in natural resources, it holds about a quarter of the forest reserves, more than half of the coal reserves, significant deposits of copper and nickel, huge energy reserves, many of which are already available" [1].

The role of Siberia is determined not only by its natural potential but also by the geographic position of this territory in our country. The pace and nature of Russia's development, both in the economic and geopolitical spheres, largely depends on the pace and nature of the development of Siberia, and vice versa. Low rates of development and positive changes in socio-economic processes in Siberia lead to a slowdown in the development of Russia. This feature of Russia's development was identified about a hundred years ago: "The main trend in the country's economic development should be considered the steadily ongoing eastward shift of economic centers" [2, p. 36]. This development trend at the very beginning of this century (meaning the twentieth century) was brilliantly foreseen by the famous Russian scientist D. I. Mendeleev. In his book "To the knowledge of Russia," he wrote "And since tundra and forests descend to lower latitudes in the north-eastern edge of Russia, com- pared with the north-west, it can be argued that the center of Russia's surface capable of resettlement lies about 56 degrees north latitude and about 46 degrees east longitude, i.e., near the border of Tobolsk and Tomsk province, slightly farther to the north of Omsk. It can be assumed that in the direction approximately to this place-with a slope to the south - the modern center of Russia's population will move in the next decade ..."

Around the same time, the outstanding Siberian scientist, professor of Tomsk Technological University B. P. Weinberg showed and formally proved the validity of his teacher's statement [3].

The authors of this article believe that Russia's rapid development is simply impossible in a situation where Siberian economic progress is hampered. Throughout almost entire past century, this statement was fair; Siberia developed at an accelerated pace, and this, in turn, largely determined the national development pace of both the economy and the social sphere. With the beginning of the $21^{\text {st }}$ century, the "continent Siberia" has stopped its targeted motion and with its "sails dropped down," it is drifting "resigning itself to winds and waves." Siberia not only started to lose the pace of development but is also steadily sliding down to the position of the country's economic outsiders. In early 2020, Rosstat published data on population dynamics in the country. Siberian regions occupy one of the leading places in terms of population decline, 
with Omsk oblast, Altai krai, Kuzbass (Kemerovo oblast) holding the sad title of "leaders" of this process [4].

In our opinion, all of the above indicates the need for a new stage of professional expert discussion of the problems and prospects of the socio-economic, scientific, and technological development of Siberia and the directions of strengthening its positions in the world and Russian space. The purpose of this article is to outline in a very concise format several major development problems of Siberia and the Siberian Federal District (SFD), to systematize a package of the most important investment projects aimed at solving these problems, and also to formulate priority measures aimed at modernizing the economic and social sphere of Siberian regions. This material, reflecting the position of the Institute of Economics and Industrial Engineering of the SB RAS, certainly does not claim to disclose all the development problems of the macroregion and ways to solve them. It opens a series of a new stage of research, expertise, preparation of scientific reports, dialog between central and regional governments, on the one hand, and authorities, scientific and expert and business communities, on the other.

Main development problems of Siberia and the Siberian Federal District, taking into account modern challenges and threats. Decline in the SFD Position in the National Economy: Lack of Progress in Solving the Problem of the Lag in the Level and Quality of Life for Siberians. In the post-Soviet period, the share of Siberian Federal District in the most important indicators of the country's development gradually decreased (see Table 1). Thus, in 1995, the share of the SFD (within modern borders) in the gross regional product (GRP) of the Russian Federation was 13.7\%; by 2017 it had decreased to $9.7 \%^{1}$. The decrease in per capita GRP in SFD was significant compared to its corresponding average value in Russia: $107.3 \%$ in 1995 and $77.6 \%$ in 2017. Over these years, the decline was observed in the district's share in all-Russian investment in fixed assets (from 11.5 to $8.9 \%$ ) and in the revenues of the consolidated budgets of the Russian Federation (from 12.8 to $10.0 \%$ ) [5]. With continuing trends for the deindustrialization of production in several regions of Siberia, no drastic turn towards accelerated growth has occurred in the processing industries either. Despite some positive shifts in the diversification level of the SFD economy due to the development of the services sector in recent years, the sectoral structure of the industry continued to degrade. Thus, the share of manufacturing in the gross industrial output of the district industry (in the volume of shipped goods) decreased from $78.5 \%$ in 1995 to $60.9 \%$ in 2017.

Of even greater concern is the situation in the social sphere. The share of the macroregion in the total Russian final consumption of households decreased from

\footnotetext{
${ }^{1}$ IfS we consider the Siberian Federal District in the initial borders (i.e., with the Republic of Buryatia and the Zabaikalsky krai), then this reduction is even more significant.
}

$12.9 \%$ in 1995 to $9 \%$ in 2017 ; the level of average annual cash incomes of the population in relation to the national average decreased from $83.2 \%$ (2005) to $76.1 \%$ (2017); and its backlog in terms of retail turnover per capita increased. There was no significant improvement in the provision of housing, utilities and basic foodstuffs to Siberians (compared to the all-Russian level). Housing in SFD, although slightly (by about 5\%) but lags behind the national indicator. As for the improvement in housing, amenities, here, according to the main indicators, the lag is noticeably greater. The morbidity rate per 1000 residents in the district in 2011-2017 increased by 4\%, while in Russia as a whole it remained almost at the same level. In 2017 , the specific morbidity rate in SFD was by $9.2 \%$ higher than the RF national average.

In general, many targeted indicators (including those related to the implementation of approved investment projects) that were stipulated by the Strategy for the Socio-Economic Development of Siberia approved in 2010 [6] failed to be met. The District switched to the trajectory of net population loss (the negative migration balance in 2018 amounted to almost 30 thousand people). This was a consequence of the continuing backlog of the Siberian regions (compared with the European regions of the country) in terms of quality and standard of living, and a decrease in demand for labor. In general, the share of the population living in the territory of the SFD (within modern borders) in the country's population decreased from $12.6 \%$ in 1995 to $11.9 \%$ in 2017 with the continuing trend for a positive balance of international population migration to the district. And this is the main negative result in the development of Siberian regions over the past quarter of the century.

Falling behind in the level of socio-economic development of Siberia and SFD and the continued dominance of their raw materials orientation are especially noticeable against the background of a significant increase in the economic potential of the northern and northeastern territories of China [7, 8] bordering Russia in the east. This growth was the result of the leadership of the PRC's targeted state policy aimed at raising the level of socio-economic development in the peripheral territories of the country, including through the implementation of the State Program for the Modernization of the Old Industrial Base of the North-East of the PRC.

The following main reasons for the failure to implement the Strategy for Socio-Economic Development of Siberia for 2010-2020 (in addition to macroeconomic and national circumstances) should be mentioned:

1. The Strategy was oriented to local (within individual federal subjects in the SFD) projects and solutions.

2. There were practically no projects (e.g., for the development in Siberia of specialized mechanical engineering for the mining, forestry, agricultural sec- 
tors of the macroregion's economy) aimed at uniting the efforts of Siberia's regions in order to ensure synergy (to obtain an additional effect) based on the interaction and cooperation of their participants.

3. The features and nature of the domestic SFD market and its potential for creating, developing, and increasing the competitive ability of the macroregion's economy as a whole were definitely underestimated.

4. Practical issues related to targeted support of cooperative ties and integration of efforts (in the form of providing targeted financial support and scientific and technical support) were insufficiently elaborated.

5 . The issues of coordination and targeted support from the macro-regional level of problems regarding the implementation of interregional projects remained unresolved.

6. Science and the local expert community was excluded from the process of discussion, maintenance, and implementation of design decisions.

Certainly, the abovementioned processes were unevenly manifested in various federal subjects within SFD. In a number of regions (for instance, in the Novosibirsk and Tomsk oblasts), positive changes were taking place, reducing the lag in the development and production efficiency, in the standard of living, and in the emergence and progress of high-tech industries. It should also be noted that in recent years the dynamics of production in the district was somewhat more favorable than in the country as a whole, but this was the result not so much of the emerging positive trends in production growth, but rather of the greater decline in the performance of the regions in the European part of Russia. The positive trends of the last decade include the fact that since 2013, labor productivity in SFD in relation to the Russian indicator has been characterized by stable positive dynamics against the background of relatively lower investment costs.

Insufficient Attention to the Problems of Siberia in the main program documents of the country's development, in the spatial policy of the Russian Federation and in Implementing the "Eastern Vector" of Russia's development. Due to the special conditions of its development (vast territories with difficult natural and climatic conditions and enormous resources remote from the economic and cultural centers of the country), a significant part of the problems noted above in the economy and social sphere of Siberia cannot be solved only at the expense of internal sources and efforts of local authorities and Siberian business. As in other large countries of the world, the development of such territories is based on a strong state support, implemented in special forms of the government spatial, structural, investment, and social policies.

However, in the last decades of the Soviet Union and in the post-Soviet period, such state attention to the problems of Siberia as the macroregion of great world and national importance had significantly weakened. This is evident from the analysis of the main program strategic documents of the Russian Federation in recent years-The Concept of LongTerm Socio-Economic Development of the Russian Federation up to 2020, the Strategy for Scientific and Technological Development of the Russian Federation up to 2035, the Strategy for Spatial Development of the Russian Federation for the Period up to 2025. Thus, in the last of them Siberian regions are not identified either as problems, or as national priorities, or as purposes [9].

Another problem is the insufficient use of the significant potential of integration interactions on the eastern borders and the weak involvement of Siberia in these processes. Although in modern conditions the "eastern vector" is recognized as the most important direction of development (and interstate interactions) of Russia, its practical implementation is fraught with serious problems, challenges, and threats. Thus, the bulk of products supplied from Russia to China is represented by Siberian fuel and raw materials (oil, natural gas, ores, metals, wood), while supplies in the opposite direction include mostly finished products. New transport corridors within the framework of the Eurasian transport system, the New Silk Road implemented by China practically bypass the Siberian space and create strong competition to Russia as a bridge between Western Europe and the Asia-Pacific countries. In eastern Russia, cross-border cooperation is developing poorly; the Russian Federation clearly concedes to China a key role in interactions with its strategic partner, Mongolia, and this key role should belong to Siberia. There are still large unused reserves in the interactions of Siberia with the countries of the southern underbelly of Asian Russia, especially with Kazakhstan.

Siberia's participation in the implementation of the strategic initiative "One belt-One road" is carried out in the format of development trying to catch up with large-scale foreign policy and economic projects of China. At the same time, on the one hand, there is practically no policy for linking this strategic initiative with the development program of the Eurasian Economic Union, on the other hand, estimates show that its implementation will have a weak effect on accelerating the development of the Siberian economy. The Russian Academy of Sciences and its institutions are not sufficiently attracted by the authorities to substantiate the main directions and assess the risks of this strategic initiative.

Thus, the RF state policy of spatial development does not sufficiently take into account the interests of Siberia. It is not accompanied by systemic economic, scientific, technical, and humanitarian interactions of the SFD regions with the countries of Northeast Asia, based on a scientifically substantiated strategy. The "eastern vector" as a priority area of spatial development and intercountry interactions in Russia does not yet have serious scientific support, and the main activ- 
ities and projects are carried out as an initiative of state corporations and vertically integrated companies. And most importantly, although with regard to their resources, economic, scientific and technological potential Siberia as a whole and SFD in particular significantly exceed the Far East and the Far Eastern Federal District, Siberia is virtually excluded from the eastern vector. So far, state support of only Far Eastern projects and strategic initiatives has prevailed in it [10].

Nevertheless, some positive trends have recently emerged that, we believe, are associated with taking an unbiased look at the effectiveness of this course. In particular, this was expressed in the federal government's supporting the initiative of the Krasnoyarsk krai and neighboring federal subjects for launching the Yenisei Siberia integration investment megaproject.

Lingering trend for defragmentation of Siberia's economic space and the lack of groundwork for effective enhancement of its cohesiveness. In the post-Soviet period, Siberia began to lose its political, geographical, and economic integrity, which undermined the development controllability of this macroregion based on the complementarity and synergy of the resource and production potential of federal subjects located in this territory.

The trend dates back to the process of reorganization and subsequent privatization of production and technological complexes that were initiated and developed in the Siberian economy. This was reflected in the almost complete elimination of specialized engineering focused on the implementation of projects taking into account the specifics of Siberia, the elimination (or catastrophic reduction) of higher valueadded production (in chemistry, petrochemistry, wood chemistry, metallurgy).

The logical continuation was the formation of federal districts, in which the traditional Siberian territories (the Tyumen oblast and its constituent AOs) were assigned to the Ural Federal District. In 2018, another "cut-off" of the economic and political space of Siberia occurred as a result of the transfer of the Republic of Buryatia and Zabaikalsky krai to the Far Eastern Federal District. Thus, it was proposed that SFD should be considered as a part of only two macroregions, the South Siberian and the Angara-Yenisei, and this was not accompanied by the necessary institutional conditions, structures, and federal support. This resulted in the loss of integrated image of the world's largest and richest macroregion, traditionally perceived by the global community as a single and historically formed Siberia.

The three decades of Siberia's development after the collapse of the Soviet Union had not involved any increase in the connectivity of its territories and regional economic complexes. The development of their integration processes was hindered by the orientation of regional political and economic elites to interregional competition seeking the attention and resources of the federal center. As a result, an increase in the competitiveness of Siberian regions was replaced by their competition and lobbying promotion of investment projects duplicating existing projects and capacities of other territories. The potential of the Interregional Association of Economic Interaction of federal subjects "Siberian Agreement," as well as sectoral interregional associations and unions of Siberia was not put to good use and was not supported by the necessary pooling of resources and opportunities in strategically important areas of economic development and the social sphere of the macroregion.

No less important, this period was not marked by large-scale transport construction of interregional rail roads and highways, which are the main material basis for the connectivity of Siberian regions. Separate transport projects were implemented in the regions (construction of new bridges and bridge crossings; construction and reconstruction of highways of regional significance, etc.). The transportation system of small aircraft was actually destroyed. The lack of a scientifically-based transport strategy of Siberia for the long term generated excessive competition in this area (for example, between the Novosibirsk and Krasnoyarsk transport and logistics hubs).

The development of the digital economy [11] and system of telecommunications, certainly, promoted the economic, scientific, technological, and cultural connectivity of the regions and cities of Siberia. It was especially important for the inclusion of remote and rural territories in these processes. At the same time, the potential for forming specialized Siberian commodity exchanges (forestry, grain, etc.) was not used. All this was exacerbated by the lack of unity among representatives of Siberian regions in the Federation Council and the State Duma preventing them from upholding their common interests.

Thus, we can talk about the fragmentation of the economic, scientific, innovative, and political space of Siberia as a fait accompli and the prevalence of centrifugal trends in the economic interaction of its regions over centripetal ones. Unfortunately, this trend can also be traced in quite progressive documents of recent times. For example, in the Angara-Yenisei Macroregion Concept of Advanced Development, prepared at the end of 2019 (developed by BCG, the Boston Consulting Group), the scenarios and main development directions of this macroregion were evaluated exclusively from narrow local (pointwise) positions, the interests of neighboring Siberian territories, their competitive advantages, and opportunities for interregional cooperation and interaction were not taken into account [12].

Absence of breakthrough in the development of highly competitive and high-tech segments of the Siberian economy, underutilized capabilities of Siberian Science. According to experts, one of the main disadvantages of the preceding period was connected precisely with the 
lack of comprehensiveness in the development of the Siberian economy. As a result, activities related to the sale of low-added-value products became more profitable, and orientation to the foreign market led to the primitivization of production and technological chains and a decrease in demand for domestic science. This led to the absence of a breakthrough in the development of highly competitive and high-tech segments of the Siberian economy and the ongoing consolidation of its raw material orientation [13].

Except the development of the Vankor field (and the VostokOil project formed on its basis [14, 15]), implementation of the Yamal-LNG project (including the construction of the Sabetta port, focused on the transportation of liquefied natural gas and ensuring year-round navigation on the Northern Sea Route) as well as the creation of super-large facilities for the production of polyethylene and polypropylene in Tobolsk (PJSC SIBUR-Holding, the project ZapSibNeftekhim), over the post-Soviet period, not a single major project of national significance was actually implemented on the territory of Siberia.

The production structure of the Siberian economy was modernized based on developing the segment of processing and high-tech industries in the following areas:

-The development of traditional high-tech defense industry segments in the Krasnoyarsk krai, Omsk, Novosibirsk and Irkutsk oblasts (aircraft, spacecraft and rockets; tank building) and new types of specialpurpose vehicles (including night-vision equipment); products of nano-, micro- and bioelectronics, etc. However, there was no noticeable increase in production here. Moreover, the task is to transfer specialized types of defense orders to other federal districts (for example, from the V. P. Chkalov Novosibirsk Aviation Plant to the Aviation Plant in Komsomolsk-onAmur).

-Modernization of the metallurgical industry in Norilsk, Kuzbass, Krasnoyarsk krai and Irkutsk oblast. The greatest successes were achieved at the aluminum smelters of Krasnoyarsk krai where a qualitative breakthrough was made in the transition to new technologies for the production of aluminum, taking into account environmental safety requirements.

-Setting up highly effective and high-tech agrifood complexes in Omsk, Novosibirsk, Tomsk oblasts, in the Krasnoyarsk and Altai krais, which practically solved the problem of providing Siberians with meat and dairy products, eggs, some types of vegetables, and culinary and confectionery products.

-Starting the transition of the timber industry of Krasnoyarsk krai and the Irkutsk oblast to the principles of "green economy" and the production of highvalue-added products (pellets, timber slab products, specified lumber, laminated articles for furniture production and home building, soluble cellulose, chemical and thermomechanical mass, etc.).
-Production of new materials (nanomaterials, including single-walled carbon nanotubes; composite materials).

-Production of catalysts for oil refining, petrochemicals, and environmental protection. In this area, SFD took the $1^{\text {st }}$ place in Russia due to the successful work of Russia's leading company SDTB Catalyst and in 2019 began the construction of the largest catalyst plant in Europe in Omsk.

-IT technologies (software systems, big data management systems, information and reference systems, speech recognition and artificial intelligence, etc.). A significant increase in this segment was observed only in certain regions of the SFD (Novosibirsk and Tomsk oblasts). Thus, in the Technopark of the Novosibirsk Academgorodok, the production volume of a company from the cluster of information technologies exceeded 15 billion rubles.

Nevertheless, in general, the structure of the SFD economy remains quite archaic. Only in the production structure of Tomsk and Novosibirsk oblasts does the share of the innovation segment exceed the average Russian level (in the Novosibirsk oblast it approached 25\%).

This is largely due both to defects in federal and regional industrial and innovation policies and to the fact that industry and other sectors of the national economy fail to use properly the latest developments in domestic science (primarily findings of the institutes of the Siberian Branch of the Russian Academy of Sciences). In the innovative economy of Siberia, special significance should be attached to those technological areas, for the application of which there are significant domestic potential demand in the region and in-house head-start findings in scientific R\&D centers. This, however, requires serious state support of regional research and innovation complexes and research and innovation clusters of Novosibirsk, Tomsk, and Krasnoyarsk, other cities of Siberia, which in the past years was extremely insufficient.

$* * *$

There are other painful problems of Siberia's socio-economic development, which weaken the possibility of realizing its unique geographical, resource, scientific, technical, and intellectual potential. Without dwelling in detail on these problems and on the special specifics of the Siberia's development in the system of national and world economics, we would like to note that the studies conducted at the Institute of Economics and Industrial Engineering of the SB RAS (including the use of original economic and mathematical tools and scenario calculations [16, 17]), allowed us to draw the following general conclusions:

1. In the face of modern challenges, threats, and global instability, Siberia can fulfill the functions of the country's most important "reserve territory," in which many of the risks for the population's develop- 
ment and life are relatively minimized. Academician V. V. Kuleshov emphasized the relevance of this circumstance in current conditions [9]. A similar conclusion was substantiated by V. P. Semenov-Tyan-Shansky with regard to the challenges and development directions of the economic and geopolitical situation in and around Russia in the first decades of the last century [18]. Recent events related to the global threat of the coronavirus pandemic show the relevance of this approach.

2. Although recently in SFD (despite the prevailing tendency to reduce its share in all-Russian investments), it is possible to maintain fairly stable dynamic and structural relations of some important indicators of socio-economic development compared to the average Russian level, this should not be the basis for complacency. Siberia in general and SFD regions, in particular, need not just stabilization of production dynamics and living standards but a significant "Siberian Breakthrough" in production dynamics and efficiency, in the quality of life for Siberians, and in the development of a progressive economy of the $21^{\text {st }}$ century.

3. Such a breakthrough is necessary not only and not so much for Siberia itself but for all Russia: due to the uniqueness of its resource and scientific and technological potential and geopolitical position, a strong and highly effective Siberia is the material basis and the ground for accelerating the development of the whole country.

The Siberian Breakthrough and the modernization of the Siberian economic system should be based on three main postulates and directions: a) expanding the internal capabilities of the Siberian regions and the maximum possible involvement of regional growth points; b) enhancing the integration and synergy of the entire Siberian economic, scientific, and technological space (the vast expanses of Siberia are not a burden, but its enormous competitive advantage). "Siberian unity" should not be a slogan, but dominant in the development of all Siberia's regions and cities; c) the Siberian Breakthrough is only possible through implementing a large package of investment projects and a system of support measures to strengthen the positions of Siberia and the SFD in the Russian economy.

Addressing Siberia's problems must be based on process-, program-, and project-oriented approach. Institute of Economics and Industrial Engineering, (SB RAS) has carried out a number of studies devoted un Siberia's socio-economic development potential [1930]. The economic recovery in Siberia in general and the SFD regions, in particular, should be based on a significant increase in investment activity at all levels: macroregional, regional and municipal. This activity should be manifested in concrete investment projects implemented both in the format of public-private partnerships and strategic initiatives of Russian and foreign investors. Currently, an understanding has been achieved about the set of new Siberian investment projects but only a part of them have been seriously economically substantiated with the associated assessment of the market situation, risks and threats. It is proposed at the interregional level, under the auspices of the Plenipotentiary Representative of the President of the Russian Federation in SFD with the participation of the Siberian Branch of the RAS and the Siberian Agreement Interregional Association, to organize a system of initiation, economic justification, and scientific and legal support of the whole complex of these projects.

The new format of industrial projects in the mineral sector involving domestic science and equipment plus deep processing (fragment): projects of the Irkutsk Oil Company. The Irkutsk Oil Company (IOC) is one of the largest independent producers of hydrocarbons (HCS) in Russia. As part of the $1^{\text {st }}$ and $2^{\text {nd }}$ stages, several natural gas treatment plants have already been built or are under construction; among those is the Ust-Kutsky gas-processing plant. At the $3^{\text {rd }}$ stage, the first ethane polymer plant will be built in Eastern Siberia and the Far East. Its completion and commissioning are scheduled for 2023. The planned output of marketable products is 650 thousand tons per year. As of 2019, more than 50 billion rubles have already been invested in the project, and the total investment will amount to over 450 billion rubles. More than 2400 jobs will be created.

Projects at the site of the Omsk oil refinery plant. The second stage of the Omsk ORP modernization scheduled to be completed in 2020 and aimed at increasing the conversion rate of oil refining to the level of the best world indicators $(97 \%)$, involves the construction of new plants and the renovation of the existing production facilities taking into account modern environmental requirements, increasing the reliability and safety of production processes. In 2019, Gazpromneft began the construction of Russia's first modern complex for the production of high-tech catalysts for oil refining. The new plant with an annual capacity of 21 thousand tons of products will ensure the production of modern catalysts for key processes of Euro-5 fuel production and deep oil refining. The technologies were developed by the company together with leading Russian research institutes (with the active participation of the Institute of Catalysis of the SB RAS).

Siberian coal projects. The implementation of coal projects in Siberia will require large investments (more than 1 trillion rubles). Investigation into the intentions of coal companies shows that their expectations are associated, first of all, with the possibility of generating income in the global market. However, due to the downward trend in global demand for coal, the lack of transport infrastructure, and tightening environmental restrictions, the priority for the coal industry in Siberia is not so much a quantitative increase in pro- 
Table 1. SFD share in the main indicators of the Russian Federation, $\%$

\begin{tabular}{l|r|r|r|r|r|r}
\hline \multicolumn{1}{c|}{ Indicator } & 1995 & 2010 & 2014 & 2015 & 2016 & 2017 \\
\hline Population & 12.6 & 12.1 & 12.0 & 12.0 & 12.0 & 12.0 \\
GRP & 13.7 & 10.2 & 9.7 & 9.7 & 9.6 & 9.7 \\
Employment & 12.8 & 13.1 & 12.8 & 12.7 & 12.6 & 12.6 \\
Investment in fixed capital & 11.5 & 9.9 & 9.9 & 9.2 & 9.1 & 9.0 \\
Final consumption & 12.9 & 9.8 & 9.4 & 9.2 & 9.1 & 9.0 \\
Consolidated budget revenues & 12.8 & 10.9 & 9.9 & 9.7 & 10.0 & 10.0 \\
\hline
\end{tabular}

Source: Statistical collections of the Federal State Statistics Service "Regions of Russia."

For comparability: all calculations excluding Crimea, SFD-within modern borders (excluding the Republic of Buryatia and Zabaikalsky krai).

duction as the transition from the sale of refined, enriched, or sorted natural raw materials to the production and marketing of its products. (The Federal Research Center for Coal and Coal Chemistry of the SB RAS in Kuzbass is actively working in this direction).

Interregional projects for modernizing production and enhancing economic space connectivity. A new quality of development of Siberia can be ensured only through the implementation of interregional projects focused on the interaction of the state and private investors in the framework of value-added chains.

Investment megaproject Yenisei Siberia is a comprehensive investment project (CIP) aimed at the development of three regions: Krasnoyarsk krai, Republic of Khakassia, and Republic of Tyva. The main objectives of the project are to intensify the socio-economic development of the regions, to enhance their investment attractiveness, to create new jobs, and to boost tax revenues and real incomes of residents of the Yenisei Siberia regions. Currently, CIP includes 32 investment projects with a total declared investment value of over 1.9 trillion rubles for the period 2019-2027. The CIP participants are more than 60 companies, including those that are leaders in world markets for industrial products [31]. At the same time, the issues of interaction between various business structures and the achievement on this basis of synergistic effects have not yet been reflected in this megaproject.

All-Siberian projects in the field of production. Of particular importance are projects for establishing stable production and technological ties between the enterprises of the mineral raw materials sector (located, as a rule, in the northern and Arctic latitudes) and the enterprises of mechanical engineering and scientific and production support, located in scientific and industrial centers of the South Siberian and Angara-Yenisei macroregions.

Reviving previously initiated all-Siberian interregional projects, which for one reason or another did not develop effectively (Siberian Biotechnological Initiative, Siberian Agricultural Engineering, the project Siberian Wild Plants etc.).
Infrastructure transport projects aimed at enhancing the connectivity of the Siberian and Far Eastern space and access to adjacent territories of other countries:

-A transborder project for organizing the interaction of the Northern Sea Route with the river waterways of the macroregion.

-Construction of the North Siberian railway.

-Establisging a network of high-speed rail links connecting the scientific and industrial centers of Novosibirsk, Omsk, Kemerovo, Tomsk, and Barnaul.

-An interregional project for the revival of small aircraft in the interest of enhancing the connectivity of Siberian territories.

-The construction of a modern latitudinal highway connecting the Republic of Khakassia with Kuzbass and Altai krai.

Projects of embedding Siberia in high-tech niches of the Russian and world economies. The Siberian response to technological challenges of the $21^{\text {st }}$ century should be based on understanding the fact that in the field of scientific and technological potential, SFD has unique advantages over other districts and macroregions of the country. Really SFD is the site of the successfully operating Siberian Branch of the Russian Academy of Sciences, its regional centers, and specific institutes, which are reputedly assessed as collectively the most effective segment of Russian science. It is the Siberian Branch of the Russian Academy of Sciences that is currently the real basis for the coherence of the scientific, technological, and educational potential of all Siberia and its intellectual community. Using its capacities will certainly contribute to Siberia's filling new technological niches in the global economic and innovation space. However, this is only possible through the implementation of specific scientific and innovative infrastructure projects and projects for setting up new high-tech industries, some of which should be accompanied by serious state support. Several types of projects have been identified here i.e.:

\section{Scientific innovative educational projects}

-The implementation, in accordance with the instructions of the President of the Russian Federa- 
tion, of the comprehensive development plan of the Siberian Branch of the Russian Academy of Sciences, taking into account the priorities and long-term development plans of SFD.

-Implementation of development programs for two territories with a high concentration of research and development (Novosibirsk and Tomsk oblasts). The most significant progress has been achieved in the implementation of the Development Program of the Novosibirsk Scientific Center as a territory with a high concentration of research and development (the mega-project Academgorodok 2.0), within the framework of which about 40 new projects have been proposed that focus on the integration of science, education and high-tech business [32].

-Implementing programs for establishing in SFD of three world-class research and educational centers (RECs) as part of the tasks of the Presidential Address on establishing 15 RECs and world-class centers of competence in Russia (Novosibirsk, Tomsk, Kemerovo).

2. Implementing projects of the strategy for scientific and technological development of the Russian Federation and the National Technological Initiative (NTI) in the territory of the Siberian Federal District)

-Projects of the series "Smart Cities of Siberia in the Digital Economy System."

-Project of the Technological National Technological Initiative "Technet-Siberia."

-Setting up the Siberian Center for Monitoring the Economy and the Natural Environment.

-Establishing the National Center for Catalyst Engineering and Testing.

As a result of implementing this package of scientific and innovative, educational projects and projects related to creating new high-tech industries, Siberia will be able, on the basis of highly competitive research and development, to occupy the following technological niches in the Eurasian Economic Union, in Northeast Asia and in cooperation with other states:

-Nuclear technologies in production and medicine (including those based on the Siberian ring photon source CCU SKIF and the Super S-Tau factory in the framework of the mega-project Akademgorodok 2.0).

-Spacecraft and avionics.

-New technologies in the field of analysis and processing of big data and artificial intelligence.

-New materials (mass production and launch of a revolutionary new material-single-walled carbon nanotubes-on the world market; new types of catalysts for petrochemistry and environmental protection; new types of composite materials; powder technology).

- Photonics, laser technologies and production of element base for micro-, bio- and nanoelectronics.

-New types of energy storage systems and devices.
-Biotechnology, genetic technology and biopharmaceuticals. $^{2}$

The upcoming stage of Siberia's development should start the launch of regional scientific and innovative conveyors, when, on the basis of integration and partnership of institutes of the Academy, universities and industrial partners, new technologies will be introduced into production and a new-breed united community of scientists and innovators will be created, successfully working in a highly competitive scientific and innovative global space.

System of high-priority measures. In order to solve the problems presented above and to implement the indicated Siberian projects, a special system of measures is required (specific measures, new strategic initiatives, regulatory support, financial and material support), which can be divided into the following two groups:

a) Measures implemented by the federal center and in various areas of national policy (structural, investment, social, innovative, spatial, scientific and technological).

b) Measures within the frame of the SFD, its regions and cities, the Siberian Branch of the RAS, associations of producers and innovators, business structures, universities, and the expert community.

The national-level measures require the following:

1) Tto reinforce the action plan for the implementation of the Strategy for Spatial Development of the Russian Federation for the period up to 2025 with a system of measures, projects and strategic initiatives to strengthen the position of Siberia in the system of the national economy and world economic relations.

2) To prepare and implement proposals for "resetting" environmental management procedures [33, 34], which should lead to a greater return on the exploitation of Siberian natural resources and a greater social effect for the regions of Siberia; this direction primarily requires establishing the procedures for "process-, project- and program-oriented approach" and regulatory systems based on the widespread use of modern digital technologies (including data centers and data analysis centers).

3) To explore the issue of setting up the National Scientific and Technological Corporation (Company) for the Development of Siberia intended to act as an integrator of regional scientific and innovation centers of the macroregion (its core may, for example, be the Novosibirsk Scientific Center, Akademgorodok 2.0) [35]).

\footnotetext{
${ }^{2}$ Thus, the Novosibirsk Scientific Center of the SB RAS and related innovative companies are at the forefront of the fight against the coronavirus pandemic in Russia. This refers to the development of the State Scientific Center for Virology and Biotechnology "Vector," institutes of the Siberian Branch of the Russian Academy of Sciences, Novosibirsk State University, the innovative company "Vector-Best" and the resident of Technopark Akademgorodok GC "Medical and Biological Union" to create vaccines, test systems, virus protection equipment, etc.
} 
In the framework of activities at the interregional and regional levels, it is necessary:

1) To carry out regionalization of national projects taking into account the interests, opportunities and specifics of specific SFD regions.

2) To prepare proposals for establishing a system of project offices and research and analytical centers (primarily for the implementation of the process approach to the implementation of projects in the macroregion).

3) To set up a system for identifying, supporting and promoting projects aimed at ensuring the connectivity of the macroregion economy and ensuring synergistic effects of the interaction between various territories and various business structures.

4) To strengthen the role of the Siberian Branch of the Russian Academy of Sciences in the scientific support of cross-border interactions in the east of Russia [36].

$$
* * *
$$

The time is ripe for emphasizing the view of Siberia as an integral whole. Institutionalization of a new development strategy for SFD in the current legal system is possible in the form of a state program for the development of the macroregion. The difference of this document from the previous Strategy should consist both in combining national projects and state programs, long-term plans of ministries, corporations and the development strategy of the Siberian regions, and in establishing and developing the process component focused on the continuous identification and development of economic cooperation opportunities within Siberia between different business agents and territories.

\section{FUNDING}

This work was prepared and supported as part of research on the plan of research of the IEIE SB RAS, project no. XI.173.1.1 "Project- and Program-oriented approach in state regional policy and in regional strategic planning and management: methodology, practice, institutes" and project no. XI.174.1.1 "The economy of Siberia and its regions in the face of external and internal challenges and threats: methodology, trends, and forecasts.”

\section{ACKNOWLEDGMENTS}

The authors of the article are deeply grateful to Academician V.V. Kuleshov, V. N.Churashov, Candidate of Economics, and senior researcher Yu. S. Ershov for the materials used, fruitful discussions and cooperation.

\section{CONFLICT OF INTEREST}

The authors declare that they have no conflicts of interest.

\section{REFERENCES}

1. The Statement by the President of the Russian Federation V.V. Putin at the plenary meeting of the St. Petersburg International Economic Forum on June 7, 2019. http://kremlin.ru/events/president/news/60707.

2. Materials for the General Plan for the Development of the National Economy of the Siberian Krai (Sibkraiizdat, Novosibirsk, 1930) [in Russian].

3. B. P. Veinberg, "The position of the center of the surface of Russia from the beginning of the Principality of Moscow to the present," Izv. Imp. Russ. Geogr. O-va. 51 (6), 365-408 (1915).

4. O. Ignatova, "Rosstat named the regions with the largest population decline." https://rg.ru/2020/02/02/regpfo/v-rosstate-nazvali-regiony-s-samoj-bolshoj-ubyliu-naseleniia.html.

5. B. L. Lavrovskii, E. A. Goryushkina, and E. A. Shil'tsin, Regional Imbalances: Russia and Siberia, Ed. by V. I. Suslov (Novosib. Gos. Tekh. Univ., Novosibirsk, 2010) [in Russian].

6. On Approval of the Strategy for Socio-Economic Development of Siberia until 2020 (as amended on December 26, 2014). The Decree of the Government of the Russian Federation of December 26, 2014 No. 1505. https://www.pravo.gov.ru.

7. PRC: The Economy of Regions, Ed. by A. V. Ostrovskii (OOO Izd. MBA, Moscow, 2015) [in Russian].

8. G. D. Kovaleva and M. Aikhemaiti, "Modern economic and institutional potential of the Xinjiang-Uygur $\mathrm{Au}-$ tonomous Region of the PRC from the perspective of inter-regional cooperation," Reg.: Ekon. Sotsiol., No. 3, 291-318 (2019).

9. V. V. Kuleshov and V. E. Seliverstov, "Role of Siberia in Russia's spatial development and its positioning in the strategy for spatial development of the Russian Federation,” Reg. Res. Russ. 8 (4), 345-353 (2018).

10. V. A. Kryukov, V. E. Seliverstov, and A. F. Braginskii, "At the tip of the eastern vector," Nauka Sib., No. 9, 4-5 (2020). http://www.sbras.info/articles/sciencestruct/ na-ostrie-vostochnogo-vektora.

11. V. D. Markova, Digital Economy. Handbook (INFRAM, Moscow, 2018) [in Russian].

12. Development and Launch of the First Clusters of Advanced Development of Central and Eastern Siberia (Aprel', Moscow, 2019), p. 76 [in Russian].

13. V. A. Kryukov, V. V. Kuleshov, and V. E. Seliverstov, "Formation of organizational and economic mechanisms for the acceleration of Siberia's socioeconomic development,” Reg. Res. Russ. 3 (4), 397-404 (2013).

14. Meeting with the Head of Rosneft Igor Sechin. http://www.kremlin.ru/events/president/news/62763.

15. V. Savel'ev and A. Uss, Yenisei Siberia: The largest project in the history of modern Russia. https://www.kommersant.ru/doc/4293096?from=region24_right.

16. A. G. Granberg, V. I. Suslov, and S. A. Suspitsyn, "Economic and mathematical studies of multi-regional systems," Reg.: Ekon. Sotsiol., No. 2, 120-150 (2008).

17. Systemic Modeling and Analysis of Meso- and Microeconomic Objects, Ed. by V. V. Kuleshov and N. I. Suslov 
(Inst. Ekon. Org. Prom. Proizvod. Sib. Otd. Ross. Akad. Nauk, Novosibirsk, 2014) [in Russian].

18. V. P. Semenov-Tyan'-Shanskii, "On powerful territorial ownership in relation to Russia," Izv. Imp. Russ. Geogr. O-va. 11 (8), 425-458 (1915).

19. Siberia in the First Decades of the 21st Century, Ed. by V. V. Kuleshov (Inst. Ekon. Org. Prom. Proizvod. Sib. Otd. Ross. Akad. Nauk, Novosibirsk, 2008) [in Russian].

20. Resource Regions of Russia in the "New Reality," Ed. by V. V. Kuleshov (Inst. Ekon. Org. Prom. Proizvod. Sib. Otd. Ross. Akad. Nauk, Novosibirsk, 2017) [in Russian].

21. The Modern Role of the Siberian Economy in the National Economic Complex of Russia, Ed. by V. V. Kuleshov (Inst. Ekon. Org. Prom. Proizvod. Sib. Otd. Ross. Akad. Nauk, Novosibirsk, 2014) [in Russian].

22. Prospects and Risks of Human Development in Siberia, Ed. by V. V. Kuleshov (Sib. Otd. Ross. Akad. Nauk, Novosibirsk, 2014) [in Russian].

23. Regional and Municipal Management of Socio-Economic Development in the Siberian Federal District, Ed. by A. S. Novoselov (Inst. Ekon. Org. Prom. Proizvod. Sib. Otd. Ross. Akad. Nauk, Novosibirsk, 2014) [in Russian].

24. From the Idea of Lomonosov to the Real Development of the Territories of the Urals, Siberia, and the Far East, Ed. by A. I. Tatarkin, V. V. Kuleshov, and P. A. Minakir (Yekaterinburg, 2009) [in Russian].

25. The Economy of Siberia: Strategy and Tactics of Modernization, Ed. by A. E. Kontorovich, V. V. Kuleshov, and V. I. Suslov (Ankil, Novosibirsk, 2009) [in Russian].

26. The Asian Part of Russia: A New Stage in the Development of the Northern and Eastern Regions of the Country, Ed. by V. V. Kuleshov (Inst. Ekon. Org. Prom. Proizvod. Sib. Otd. Ross. Akad. Nauk, Novosibirsk, 2008) [in Russian].

27. The Formation of an Enabling Environment for Living in Siberia, Ed. by V. V. Kuleshov (Inst. Ekon. Org. Prom.
Proizvod. Sib. Otd. Ross. Akad. Nauk, Novosibirsk, 2010) [in Russian].

28. V. A. Kryukov, "Studying the economy of Siberia: Continuity and integrity," Reg. Res. Russ. 9 (2), 107117 (2019).

29. V. I. Suslov, "Siberia as a megaregion: Economic parameters and development strategies," in Siberia as a Megaregion: Parameters and Goals, Ed. by V. I. Suprun (Trendy, Novosibirsk, 2018), pp. 70-86 [in Russian].

30. V. I. Suslov and V. G. Basareva, "Megaregion Siberia: Potential and prospects of socio-economic development," in Analysis, Modeling, Management, and Development of Socio-Economic Systems (AMUR-2019): Collection of Scientific Papers of the XIII All-Russian School-Symposium with International Participation, September 14-27, 2019, Simferopol-Sudak, Ed. by advice: A. V. Sigal et al. (IP Kornienko, Simferopol, 2019), pp. 377-382.

31. Yenisei Siberia. https://ensib.ru/.

32. V. N. Parmon, "2010s and beyond: Rebooting without logging off," Nauka Sib., Sept. 13 (2019). http://www.sbras.info/articles/sciencestruct/2010-e-idalshe-perezagruzka-bez-vykhoda-iz-sistemy.

33. The Mineral Resource Sector of Asian Russia: How to Ensure Socio-Economic Returns, Ed. by V. V. Kuleshov (Inst. Ekon. Org. Prom. Proizvod. Sib. Otd. Ross. Akad. Nauk, Novosibirsk, 2015) [in Russian].

34. V. Kryukov, "Energy and natural resources," in Russia: Strategy, Policy, and Administration, Ed. by I. Studin (Palgrave Macmillan UK, Basingstoke, 2018), pp. 205-215.

35. V. E. Seliverstov, "Akademgorodok 2.0: Development scenarios and management system," Reg.: Ekon. Sotsiol., No. 4, 24-54 (2019).

36. V. N. Parmon, V. A. Kryukov, and V. E. Seliverstov, "Cross-border interactions in the East of Russia: Scientific support and tasks of the Siberian Branch of the RAS,” Reg.: Ekon. Sotsiol., No. 2, 226-258 (2020).

Translated by I. Pertsovskaya 